\title{
Diastrophic Dysplasia
}

National Cancer Institute

\section{Source}

National Cancer Institute. Diastrophic Dysplasia. NCI Thesaurus. Code C156311.

An autosomal recessive condition caused by mutation(s) in the SLC26A2 gene, encoding sulfate transporter. It is characterized by cartilaginous and bony abnormalities, in particular very short arms and legs and the "hitchhiker" thumb, resulting from deformity of the first metacarpal. 